\title{
RELACIJE KARAKTERISTIKA PORODICE I PREVLADAVANJA STRESA KOD ADOLESCENATA
}

\author{
Marija Zotović', Tijana Telečki, Ivana Mihić i Jelica Petrović \\ Odsek za psihologiju, Filozofski fakultet, Novi Sad
}

Cilj ovog istraživanja je bio ispitivanje povezanosti između načina prevladavanja stresa kod adolescenata $i$ nekih karakteristika porodice. Istraživanje je sprovedeno na uzorku od 201 adolescenta, uzrasta od 15 do 19 godina. Redukcija početnog skupa varijabli je obavljena hijerarhijskom faktorskom analizom, dok je povezanost izmedu prevladavanja stresa $i$ karakteristika porodice ispitana Pirsonovim koeficijentom korelacije. Rezultati pokazuju da se za prevladavanje stresa kod adolescenata koristi devet različitih strategija, koje se mogu svesti na 3 osnovne dimenzije: aktivno prevladavanje, prevladavanje usmereno na emocije $i$ pasivno prevladavanje. Rezultati takođe pokazuju da kod adolescenata postoji statistički značajna povezanost pozitivnog smera između porodične kohezivnosti sa jedne strane, i na emocije usmerenog prevladavanja $i$ aktivnog prevladavanja stresa sa druge strane. Registrovana je $i$ povezanost porodične fleksibilnosti $i$ na emocije usmerenog prevladavanja stresa. Statistički značajna povezanost negativnog smera dobijena je između porodične kohezivnosti i izbegavajućeg prevladavanja stresa.

Ključne reči: karakteristike porodice, prevladavanje stresa, adolescenti

\footnotetext{
1E-mail: zotovic@eunet.yu; Rad je u okviru projekta «Psihološke karakteristike društva u tranziciji» koji podržava Ministarstvo nauke i zaštite životne sredine, broj 149008
} 


\section{Uvod}

Proteklih godina svedoci smo mnogih društvenih promena u našoj zemlji i okolnim regionima. Uticaj ovih promena očigledan je i osetan i na mnogim poljima svakodnevnog funkcionisanja pojedinaca. Pod uticajem ovih promena neminovno se nalazi i porodica, koja predstavlja medijator između potreba pojedinca i društva. Cilj ovog rada je da se ispita koje karakteristike porodice, mogu da doprinesu prilagođavanju i prevladavanju stresa kod pojedinaca.

Usredsređenost ovog rada prvenstveno na period adolescencije zasnovan je na saznanju da adolescencija sama po sebi predstavlja period sa povećanim zahtevima za prilagođavanjem na promene u mnogim oblastima funkcionisanja, te se pretpostavlja da je to prilagođavanje još dodatno otežano navedenim društvenim procesima. Može li porodica adolescentu olakšati pri-lagođavanje i odrastanje i u ovakvim otežanim društvenim uslovima osnovno je pitanje koje je ispitivano u okviru ovog istraživanja.

Kao teorijski okvir za istraživanje karakteristika porodice koje bi mogle doprineti efikasnom prevladavanju stresa korišćen je Olsonov cirkumpleks model porodičnih i bračnih sistema. Autor Cirkumpleks modela, D. Olson, (Olson \& Gorall, 2003) ponudio je trodimenzionalno rešenje predstavljanja osnovnih tipova porodice, kao i efikasnosti njihovog prevladavanja normativnih stresora. Olson je izdvojio tri osnovne dimenzije koje sadrži model: kohezivnost, fleksibilnost (adaptabilnost) i komunikaciju.

Dimenzija kohezivnost je u ovom modelu shvaćena kao emotivna vezanost (privrženost) među članovima porodice (Riesch et al., 2003). Kohezivnost može biti izražena kroz četiri nivoa:

- razjedinjenost - veoma nizak nivo kohezivnosti;

- izdvojenost - nizak do umeren nivo kohezivnosti;

- povezanost - umeren do visok nivo kohezivnosti;

- isprepletenost - veoma visok nivo kohezivnosti.

Kada je Olson konceptualizovao ovaj model, smatrao je da je središnji nivo kohezivnosti optimalan za funkcionisanje porodice, a da su ekstremi nepoželjni. Međutim, neka empirijska istraživanja dala su rezultate koji govore o tome da što je kohezivnost između članova porodice veća, to je funkcionisanje porodice optimalnije (Gaughan, 1995; Green et al., 1991; Henggler et al., 1991; Olson, 1991, prema Riesch et al., 2003).

Dimenzija fleksibilnost (ili adaptabilnost) se shvata kao sposobnost i spremnost porodice da menja svoju strukturu moći, odnose uloga i pravila zarad 
sopstvenog razvoja (Riesch et al., 2003). I dimenzija fleksibilnosti može imati četiri nivoa:

- rigidnost - veoma nizak nivo fleksibilnosti;

- strukturisanost - nizak do umeren nivo fleksibilnosti;

- fleksibilnost - umeren do visok nivo fleksibilnosti;

- haotičnost - veoma visok nivo fleksibilnosti.

I za ovu dimenziju Olson pretpostavlja da je za dobro porodično funkcionisanje optimalan središnji nivo (strukturisanost i fleksibilnost).

Treća dimenzija cirkumpleks modela, komunikacija, smatra se dimenzijom koja služi pospešivanju prethodne dve dimenzije. Ona je određena kao ekspresija misli i osećanja na asertivan način, kao i pažljiva i tačna recepcija (prijem) tuđih misli i osećanja (Robin, 1979, prema Riesch et al., 2003). Ona se procenjuje kroz veštine slušanja i govorenja članova porodice, jasnoću govora, mogućnost praćenja kontinuiteta razgovora, kao i uvažavanje i poštovanje drugih naspram isticanja sebe (Mitić, 1997). Karakteristike adekvatne komunikacije, koja omogućuje porodici da postigne optimalan nivo kohezivnosti i fleksibilnosti, bile bi sledeće: jasan i kongruentan sadržaj poruke, empatičnost, aktivno slušanje, pružanje podrške i efikasnost u rešavanju problema. Sa druge strane, neadekvatna komunikacija odlikovala bi se sledećim karakteristikama: nekongruentan sadržaj koji diskvalifikuje sagovornika, nedostatak empatije i podrške upućene sagovorniku, kriticizam, neefikasnost u rešavanju problema, kao i protivurečne i poruke sa dvostrukim značenjem. Ovakva komunikacija onemogućava članovima porodice da razmenjuju misli i osećanja, što za posledicu ima smanjenu mogućnost promene nivoa kohezivnosti i fleksibilnosti (Riesch et al., 2003).

$\mathrm{Na}$ osnovu ovih dimenzija, porodice se mogu podeliti u četiri balansirana, četiri ekstremna i četiri tipa srednjeg obima. Balansirani tipovi porodice su: fleksibilno - izdvojene, fleksibilno - povezane, strukturisano - izdvojene i strukturisano - povezane. Ostali tipovi porodica smatraju se u manjoj ili većoj meri disfunkcionalnim.

\section{Karakteristike porodice sa adolescentom}

Porodica kao relativno trajna društvena grupa, tokom svog ciklusa postojanja prolazi kroz razne faze promena svoje socio - psihološke dinamike. Uporedo sa razvojem pojedinaca, njenih članova, menja se i njena grupna dinamika 
zasnovana na (razvojnim) promenama individualnih karakteristika pojedinaca koje dovode do promena u njihovim međusobnim odnosima.

Kada je u pitanju kohezivnost, u literaturi postoje dva gledišta o karakteristikama porodice tokom adolescencije. Prvo gledište pretpostavlja promenu u kvalitetu porodičnih odnosa (Conger \& Ge, 1999; Laursen \& Collins, 1994; Smetana, 1988, prema Baer, 2002). Postoje tri grupe teorija u kojima je zastupljeno ovo shvatanje: psihoanalitička, biosocijalna i kognitivna. Psihoanalitički model pretpostavlja emocionalno distanciranje i povlačenje psihičke energije od roditelja kao deo procesa odrastanja (sazrevanja) (Blos, 1979, prema Baer, 2002). Biosocijalni modeli govore o emocionalnom distanciranju od roditelja kao preduslovu za uspostavljanje partnerskih (seksualnih) odnosa. Kognitivni modeli postuliraju emocionalno distanciranje kao fundamentalno za promenu od jednostranog ka zajedničkom donošenju odluka (Smetana, 1988, prema Baer, 2002). Ove teorije takođe podrazumevaju i smanjenje porodične kohezivnosti u periodu kada su deca u porodici na adolescentnom uzrastu.

Za razliku od spomenutog shvatanja, modeli socijalnih relacija pretpostavljaju kontinuitet $\mathrm{u}$ emocionalnoj vezanosti između roditelja i adolescenata. Prema ovom shvatanju porodična kohezivnost je fundamentalna, jer se smatra da privrženost roditeljima, emocionalna bliskost i osećaj podrške sa njihove strane podstiču i olakšavaju razvoj u adolescenciji (Laursen \& Collins, 1994, prema Baer, 2002). Smatra se da porodična kohezivnost deluje kao zaštitni faktor od psihosocijalnih stresora koji su nerazdvojno vezani za razvoj. Uz to, porodična kohezivnost doprinosi i međusobnoj saradnji roditelja i adolescenata (Baer, 2002).

Što se tiče druge, po Olsonu, najznačajnije karakteristike porodice, adaptabilnosti (fleksibilnosti), Olson (1986, prema Farrell \& Barnes, 1993) sam, sugeriše porast porodične fleksibilnosti (približavanja haotičnom ekstremu) tokom stadijuma porodice kada su deca adolescenti. Ističe se, međutim, i da adolescenti istovremeno svoje porodice percipiraju kao manje kohezivne i rigidnije nego njihovi roditelji (Farrell \& Barnes, 1993). To se može razumeti u kontekstu povećane potrebe za autonomijom tokom adolescentnog uzrasta, što ima uticaja na percepciju kohezivnosti i fleksibilnosti. Kada je reč o balansiranim tipovima porodice (a ne ekstremnim) pretpostavlja se da će roditelji više ili manje uspešno odgovoriti na veću izraženost ove potrebe kod adolescenata, te da će i sami sa većom fleksibilnošću pristupati njihovim zahtevima, što će dovesti do povećanja nivoa fleksibilnosti na nivou cele porodice u odnosu na ranije. 


\section{Prevladavanje stresa}

Prevladavanje stresa poseban značaj dobija u transakcionističkom shvatanju stresa. Za razliku od ranijeg shvatanja, kada je prevladavanje shvaćeno kao "stabilna i relativno trajna karakteristika ili crta osobe" (Haan, 1977; Vaillant, 1977), u okviru transakcionističke teorije stresa, Lazarus prevladavanje shvata kao proces i određuje, kao sve ono što osoba čini na kognitivnom ili bihevioralnom planu sa ciljem rešavanja problema i/ili smanjenja intenziteta psihofiziološke reakcije u okviru stres procesa (Lazarus \& Folkman, 1984). Prema ovoj definiciji, prevladavanje ima dve osnovne funkcije: rešavanje problema i emocionalnu regulaciju.

Zbog velikog broja različitih oblika prevladavajućih ponašanja, mnogi autori koji su se bavili ovom tematikom, pokušali su da pronađu dimenzije koje stoje u osnovi raznolikosti prevladavajućih reagovanja. Broj dimenzija koje su ustanovljene prvenstveno zavisi od hijerarhijskog nivoa koncepta prevladavanja, tj. da li je ono shvaćeno kao stil koji predstavlja opštu dispoziciju za određeni način ponašanja u okolnostima koje su prethodno procenjene kao stresne, ili kao strategija koja predstavlja prevladavajuće reagovanje koje je vezano za specifičnu stresnu situaciju. Stilovi prevladavanja podrazumevaju preferenciju upotrebe određenih strategija prevladavanja.

Osnovne dimenzije prevladavanja predložilo je nekoliko autora prema različitim kriterijumima. Krohne prema fokusu pažnje razlikuje dve osnovne dimenzije prevladavanja: usmeravanje pažnje, koje podrazumeva stilove prevladavanja koji uključuju intenzivno traganje za informacijama vezanim za stresni događaj i njihovu obradu; i kognitivno izbegavanje koje se odnosi na odvraćanje pažnje od bilo kakvih stimulusa i informacija vezanih za stresni događaj. Drugi autori ove iste dimenzije nazivaju pristupajuće, aktivno nasuprot izbegavajućem, pasivnom prevladavanju (Ebata \& Moos, 1991; Roth \& Cohen, 1986, prema Zotović, 2004).

Iako prevladavanje analiziraju prvenstveno na nivou strategija prevladavanja, za koje smatraju da su situaciono specifične, Lazarus i Folkman ipak smatraju da se različite strategije na osnovu funkcije mogu svrstati u dve kategorije: na problem usmereno i na emocije usmereno prevladavanje (Lazarus \& Folkman 1984). U prvom slučaju prevladavanje se sastoji od akcija koje su usmerene na rešavanje problematične situacije ili odnosa između osobe i situacije, a u drugom je reč o strategijama za odvlačenje pažnje ili drugim svesnim aktivnostima sa ciljem regulacije neprijatnog afekta, kao i o kognitivnim strategijama pridavanja drugačijeg značenja stresnoj situaciji. Ove dru-ge ne menjaju direktno stresnu situaciju već su usmerene na osobu na koju je delovao 
stresor. U realnom procesu prevladavanja navedeni različiti vidovi prevladavanja se ne isključuju.

\section{Problemi i ciljevi istraživanja}

Ovo istraživanje je sprovedeno da bi se dobili odgovori na sledeća istraživačka pitanja:

-Koje su bazične dimenzije prevladavanja stresa kod adolescenata?

-Kako adolescenti procenjuju funkcionisanje svojih porodica?

-Kakva je povezanost porodičnih karakteristika (kohezivnost i

fleksibilnosti) i prevladavanja stresa kod adolescenata?

\section{Metod}

\section{Uzorak}

Uzorak ispitanika su činili adolescenti uzrasta od 15 do 19 godina, učenici Srednje ekonomske škole i Gimnazije „Svetozar Marković“ u Novom Sadu. Ukupan broj ispitanika je bio 201, 86 muškog i 115 ženskog pola.

\section{Instrumenti}

U istraživanju su korišćeni sledeći instrumenti:

- A - COPE (Adolescent Coping Orientation for Problem Experiences; Patterson \& McCubbin, 1987). Instrument je namenjen identifikovanju osnovnih strategija prevladavanja i ponašanja u susretu sa razvojnim stresovima $\mathrm{u}$ adolescenciji. Autori ovog upitnika su utvrdili da su ajtemi raspoređeni u 12 faktora: ventiliranje osećanja, traženje preokupacije, razvijanje samopouzdanja i optimizma, traženje socijalne podrške, rešavanje porodičnih problema, izbegavanje problema, traženje duhovne podrške, ulaganje $u$ odnose sa bliskim prijateljima, traženje profesionalne pomoći, uključivanje u zahtevne aktivnosti, upotreba humora i relaksacija. Sastoji se od 54 ajtema. Format za odgovaranje je petostepena skala Likertovog tipa (od 1 - nikad do 5 - uvek).

Relijabilnost upitnika na uzorku iz ovog istraživanja iznosi: Cronbach $\alpha=0,79$.

- FACES III (Family Adaptibility \& Cohesion Scale; Olson et al, 1985). Skala je namenjena proceni dve dimenzije Cirkumpleks modela: porodične adapta- 
bilnosti (fleksibilnosti) i kohezivnosti. Sastoji se od 20 ajtema, po 10 za svaku dimenziju, raspoređenih naizmenično. Format za odgovaranje je petostepena skala Likertovog tipa (od 1 - skoro nikad do 5 - skoro uvek).

Pouzdanost izražena Cronbachovim koeficijentom dobijena na uzorku iz ovog istraživanja iznosi: $\alpha=0,82$ za ceo upitnik, $\alpha=0,66$ za skalu porodične adaptabilnosti (fleksibilnosti) i $\alpha=0,86$ za skalu porodične kohezivnosti.

\section{Postupak}

Za potrebe istraživanja sprovedeno je grupno testiranje. Ispitanicima je dato generalno uputstvo na početku ispitivanja kao i posebna uputstva za svaki instrument. Vreme za popunjavanje upitnika nije bilo ograničeno. Istraživanje je sprovedeno tokom novembra i decembra 2007. godine u Srednjoj ekonomskoj školi „Svetozar Miletić“ i Gimnaziji „Svetozar Marković” u Novom Sadu.

\section{Metode analize podataka}

U cilju redukcije početnog skupa varijabli na upitniku A - COPE je primenjena hijerarhijska faktorska analiza. Odgovori ispitanika su svedeni na 9 faktora prvog, a zatim i na 3 faktora drugog reda.

Povezanost karakteristika porodice i načina prevladavanja stresa kod adolescenata ispitana je Pirsonovim koeficijentom korelacije.

\section{Rezultati}

\section{Dimenzije prevladavanja stresa kod adolescenata}

Dimenzije prevladavanja stresa kod adolescenata registrovane su uz pomoć hijerarhijske faktorske analize upitnika A - COPE. Prvobitno je kosouglom Promax rotacijom izdvojeno, na osnovu Cattellovog grafičkog kriterijuma, 9 faktora prvog reda koji objašnjavaju 50,26\% ukupne varijanse. Na njima je zatim urađena faktorska analiza drugog reda, da bi se došlo do bazičnih načina prevladavanja. Pri tome su kosom Promax rotacijom izdvojena 3 faktora sa vrednošću karakterističnih korenova $\lambda>1$, koji objašnjavaju 48,93\% varijanse.

Sledi prikaz faktora drugog reda sa korelacijama faktora prvog reda koji ih opisuju. 
Prvi faktor drugog reda dobio je naziv aktivno prevladavanje. Ovaj faktor čine strategije koje karakteriše aktivan pristup situaciji, nastojanje da se održi rutina i smanji napetost. U ovaj faktor ulaze i strategije prevladavanja koje uključuju traženje podrške, što takođe odslikava aktivan pristup. U tabeli 1 . prikazana je struktura prvog faktora drugog reda.

Tabela 1. Struktura prvog izolovanog faktora drugog reda

\section{FAKTOR I: aktivno prevladavanje}

\begin{tabular}{|c|c|c|}
\hline $\mathbf{r}$ & faktori prvog reda & primer ajtema \\
\hline .702 & F4: održavanje rutine & $\begin{array}{l}\text { Ispunjavam zahteve roditelja i pridržavam se } \\
\text { njihovih pravila (.648) }\end{array}$ \\
\hline .702 & $\begin{array}{l}\text { F8: traženje duhovne } \\
\text { podrške }\end{array}$ & $\begin{array}{l}\text { Odlazim u crkvu i pričam sa sveštenim licima } \\
\text { (.718) }\end{array}$ \\
\hline .644 & $\begin{array}{l}\text { F2: traženje podrške od } \\
\text { prijatelja }\end{array}$ & $\begin{array}{l}\text { Pričam sa prijateljima o onome što me muči } \\
(.714)\end{array}$ \\
\hline .513 & $\begin{array}{l}\text { F1: održavanje aktivnosti } \\
\text { i razvijanje optimizma }\end{array}$ & $\begin{array}{l}\text { Organizujem svoj život i aktivnosti (trčim, } \\
\text { vozim bicikl) (.694) } \\
\text { Pokušavam da u teškim situacijama vidim } \\
\text { nešto dobro }(.683)\end{array}$ \\
\hline
\end{tabular}

Drugi faktor drugog reda dobio je naziv na emocije usmereno prevladavanje. Ovaj faktor čine faktori prvog reda koji obuhvataju ponašanja usmerena na emocionalnu regulaciju, od kojih su neke strategije više aktivne u postizanju cilja (emocionalna ventilacija u krugu porodice), a neke manje aktivne (rasterećujuće aktivnosti). U tabeli 2. data je struktura opisanog faktora.

Tabela 2. Struktura drugog izolovanog faktora drugog reda

\section{FAKTOR II: na emocije usmereno prevladavanje}

\begin{tabular}{|c|c|c|}
\hline $\mathbf{r}$ & faktori prvog reda & primer ajtema \\
\hline .706 & $\begin{array}{l}\text { F 3: emocionalna } \\
\text { ventilacija u } \\
\text { krugu porodice }\end{array}$ & $\begin{array}{l}\text { Izduvam se tako što pričam sa nekim u porodici } \\
\text { (.764) } \\
\text { Razgovaram sa tatom o onome što me muči } \\
(.731)\end{array}$ \\
\hline .615 & $\begin{array}{l}\text { F 7: suzdržavanje od } \\
\text { ispoljavanja } \\
\text { negativnog afekta }\end{array}$ & $\begin{array}{l}\text { Besan sam i vičem na druge }(-.666) \\
\text { Govorim drugima ružne stvari }(-.646)\end{array}$ \\
\hline .608 & $\begin{array}{l}\text { F 9: rasterećujuće } \\
\text { aktivnosti }\end{array}$ & $\begin{array}{l}\text { Čitam (.566); Idem u bioskop (.556) } \\
\text { Bavim se hobijem (.453) }\end{array}$ \\
\hline
\end{tabular}


Treći faktor, kome je dat naziv pasivno prevladavanje opisuju primarni faktori koji se odnose na izbegavajuće oblike ponašanja i pasivan odnos prema situaciji, što uključuje potiskivanje neprijatnih osećanja, i odsustvo ponašanja usmerenih na rešavanje problema. U tabeli 3. prikazana je struktura trećeg faktora drugog reda.

Tabela 3. Struktura trećeg izolovanog faktora drugog reda

\section{FAKTOR III: pasivno prevladavanje}

\begin{tabular}{cll}
\hline $\mathbf{r}$ & \multicolumn{1}{c}{ faktori prvog reda } & \multicolumn{1}{c}{ primer ajtema } \\
\hline .849 & $\begin{array}{l}\text { F 6: izbegavanje } \\
\text { konfrontacije i } \\
\text { zloupotreba supstanci }\end{array}$ & $\begin{array}{l}\text { Viđam se sa momkom/devojkom (.653) } \\
\text { Pijem pivo, vino i žestinu (.610) }\end{array}$ \\
.485 & F 5: pasivnost & Gledam TV (.690); Spavam (.647) \\
\hline
\end{tabular}

U daljoj obradi podataka korišteni su faktorski skorovi ispitanika na faktorima prvog i drugog reda.

\section{Karakteristike porodica iz uzorka}

Prosečne vrednosti na dimenzijama kohezivnosti i fleksibilnosti FACES upitnika, prikazane u tabeli 4, ukazuju na visoke skorove na obe dimenzije.

Tabela 4. Desktiptivni pokazatelji za skalu FACES

\begin{tabular}{lcccc}
\hline & min & max & AS & SD \\
\hline porodična kohezivnost & 7 & 50 & 35.55 & 7.71 \\
porodična fleksibilnost & 14 & 50 & 27.16 & 5.84 \\
\hline
\end{tabular}

Iako je prema normama koje je za našu populaciju dala M. Mitić (Mitić, 1997), većina porodica iz uzorka smeštena u balansirane, funkcionalne sisteme, skorovi na subskalama ukazuju na visoke nivoe kada su u pitanju obe procenjivane dimenzije porodičnog funkcionisanja.

\section{Ispitivanje povezanosti karakteristika porodice i prevladavanja stresa}

Povezanost karakteristika porodice i prevladavanja stresa ispitana je uz pomoć Pirsonovog koeficijenta korelacije. Povezanost je najpre ispitana između karakteristika porodice (kohezivnosti i fleksibilnosti) i stilova prevladavanja 
stresa, operacionalizovanih putem faktorskih skorova ispitanika na faktorima drugog reda iz upitnika A-COPE. Rezultati su prikazani u Tabeli 5.

Tabela 5. Vrednosti Pirsonovih koeficijenata korelacije-stilovi prevaladavanja

\begin{tabular}{lcccc}
\hline & \multicolumn{2}{c}{ kohezivnost } & \multicolumn{2}{c}{ fleksibilnost } \\
\cline { 2 - 5 } \multicolumn{1}{c}{ Stilovi prevladavanja stresa } & $\mathbf{r}$ & $\mathbf{p}$ & $\mathbf{r}$ & $\mathbf{p}$ \\
\hline F1: aktivno prevladavanje & .279 & .01 & .064 & n.z. \\
$\begin{array}{l}\text { F2: na emocije usmereno } \\
\text { prevladavanje }\end{array}$ & .464 & .01 & .195 & .01 \\
\begin{tabular}{l} 
F3: pasivno prevladavanje \\
\hline
\end{tabular} & -.176 & .05 & .078 & n.z. \\
\hline
\end{tabular}

Iz tabele se vidi da su se kao značajne pokazale korelacije između porodične kohezivnosti i aktivnog prevladavanja, kao i prevladavanja usmerenog na emocije na nivou značajnosti $\mathrm{p}<0,01$, s tim što je korelacija sa prevladavanjem usmerenim na emocije većeg intenziteta. $U$ oba slučaja je prisutna povezanost pozitivnog smera, što ukazuje na to da se kod adolescenata sa povećanjem porodične kohezivnosti povećava i učestalost aktivnog prevladavanja stresa, a pogotovo na emocije usmerenog prevladavanja. Pored toga, slaba korelacija negativnog smera između porodične kohezivnosti i pasivnog prevladavanja, na nivou značajnosti $p<0,05$, ukazuje na smanjenje učestalosti pasivnog, izbegavajućeg prevladavanja stresa kod adolescenata, sa povećanjem porodične kohezivnosti.

Vrednosti koeficijenta korelacije između porodične fleksibilnosti i na emocije usmerenog prevladavanja govori o postojanju slabe pozitivne povezanosti između ovih varijabli, tj. da sa povećanjem porodične fleksibilnosti raste i učestalost na emocije usmerenog načina prevladavanja kod adolescenata.

Analizom povezanosti između karakteristika porodice (kohezivnosti i fleksibilnosti) i strategija prevladavanja stresa, operacionalizovanih putem faktorskih skorova ispitanika na faktorima prvog reda iz upitnika A-COPE, dobijen je precizniji uvid u odnose između ovih varijabli. Rezultati su prikazani u tabeli 6. 
Tabela 6. Vrednosti Pirsonovih koeficijenata korelacije-strategije prevladavanja

\begin{tabular}{|c|c|c|c|c|}
\hline \multirow[t]{2}{*}{ Strategije prevladavanja stresa } & \multicolumn{2}{|c|}{ kohezivnost } & \multicolumn{2}{|c|}{ fleksibilnost } \\
\hline & $\mathbf{r}$ & $\mathbf{p}$ & $\mathbf{r}$ & $\mathbf{p}$ \\
\hline $\begin{array}{l}\text { F1: održavanje aktivnosti i razvijanje } \\
\text { optimizma }\end{array}$ & .353 & .01 & .095 & n.z. \\
\hline F2: traženje podrške od prijatelja & .110 & n.z. & .051 & n.z. \\
\hline $\begin{array}{l}\text { F3: emocionalna ventilacija u krugu } \\
\text { porodice }\end{array}$ & .500 & .01 & .252 & .01 \\
\hline F4: održavanje rutine & .150 & .05 & -.009 & n.z. \\
\hline F5: pasivnost & -.031 & n.z. & .043 & n.z. \\
\hline $\begin{array}{l}\text { F6: izbegavanje konfrontacije i } \\
\text { zloupotreba supstanci }\end{array}$ & .229 & .01 & .075 & n.z. \\
\hline $\begin{array}{l}\text { F7: suzdržavanje od ispoljavanja } \\
\text { negativnog afekta }\end{array}$ & .199 & .01 & .021 & n.z. \\
\hline F8: traženje duhovne podrške & .119 & n.z. & .044 & n.z. \\
\hline F9: rasterećujuće aktivnosti & .209 & .01 & .088 & n.z. \\
\hline
\end{tabular}

Iz Tabele 6 se vidi da postoji značajna povezanost između porodične kohezivnosti i svih strategija prevladavanja koje su uključene u domen na emocije usmerenog stila. Povezanost je najizraženija sa strategijom prevladavanja koja uključuje emocionalnu ventilaciju u krugu porodice. Povezanost kohezivnosti sa drugim strategijama koje opisuju na emocije usmeren stil prevladavanja (suzdržavanje od ispoljavanja negativnog afekta i rasterećujuće aktivnosti) je u domenima slabog intenziteta.

Kada su u pitanju strategije koje opisuju stil aktivnog prevaladavanja stresa, kohezivnost ostvaruje značajne korelacije srednjeg intenziteta sa strategijom održavanje aktivnosti $i$ razvijanje optimizma. Ostale strategije koje opisuju ovaj stil, ne ostvaruju značajne korelacije sa procenjenom kohezivnošću unutar porodice.

Iako pasivno prevladavanje ostvaruje korelacije sa kohezivnošću porodice na granici statističke prihvatliivosti, strategija izbegavanje konfrontacije i zloupotreba supstanci, koja zasićuje ovaj stil, povezana je sa kohezivnošću u domenu slabe do umerene vrednosti.

Porodična fleksibilnost je pokazala slabu povezanost samo sa jednom strategijom prevladavanja stresa, a to je emocionalna ventilacija u krugu porodice. Sa drugim strategijama koje opisuju na emocije usmeren stil prevladavanja, ili 
bilo koji drugi stil, procenjena fleksibilnost porodice nije ostvarila značajnu povezanost.

\section{Diskusija}

Rezultati registrovanja bazičnih dimenzija prevladavanja stresa kod adolescenata, na osnovu različitih strategija prevladavanja $u$ susretu sa stresovima $u$ svakodnevnom životu, pokazuju da je kod adolescenata strategije prevladavanja moguće svesti na tri dimenzije: 1. aktivno prevladavanje, 2. prevladavanje usmereno na emocije i 3. pasivno prevladavanje. Navedene dimenzije prevladavanja, koje su faktorskom analizom izolovane u ovom istraživanju, uklapaju se u dva najrasprostranjenija stanovišta o dimenzijama prevladavanja i predstavljaju kombinaciju ova dva shvatanja. Prvo shvatanje zastupaju autori koji razlikuju stilove prevladavanja prema fokusu pažnje (Byrne, 1964, Roth \& Cohen, 1986, Miller, 1987, Ebata \& Moos, 1991, Krohne, 1993). Ovi autori stilove prevladavanja dele na: usmeravanje pažnje (pristupajuće, aktivno) i kognitivno izbegavanje (izbegavajuće, pasivno). Drugo shvatanje zastupaju Lazarus i Folkman (Lazarus \& Folkman 1984), po kojima prevladavanje može biti usmereno na problem i usmereno na emocije, u zavisnosti od njegove funkcije. Iako dobijeni rezultati ne uključuju sve četiri očekivane kategorije prevladavanja, oni ukazuju na to da se realna prevladavajuća ponašanja ne mogu svrstati samo u dve kategorije, bez obzira o kom od modela je reč. Slične tri dimenzije prevladavanja dobijene su u skorašnjem istraživanju $u$ kome je takođe korišćen instrument A-COPE na adolescentnoj populaciji (Zotović i sar., 2008).

Ispitivanjem povezanosti prevladavanja stresa i karakteristika porodice, dobijeni su rezultati koji pokazuju da adolescenti imaju različite strategije i stilove prevladavanja stresa $u$ zavisnosti od procenjenih nivoa kohezivnosti i fleksibilnosti u porodicama u kojima žive. Za adolescente iz porodica sa višim nivoom kohezivnosti i fleksibilnosti karakteristično je na emocije usmereno prevladavanje, pre svega emocionalna ventilacija u krugu porodice. Za kohezivnije porodice, karakteristično je i aktivno prevladavanje, koje se manifestuje pre svega kao održavanje aktivnosti i razvijanje optimizma.

U tumačenju veće zastupljenosti na emocije usmerenog prevladavanja u kohezivnijim porodicama, treba imati u vidu da porodična kohezivnost pretpostavlja emocionalnu povezanost i bliskost članova porodice. Moguće je da se u ovakvim porodicama neguje prevladavanje koje je usmereno na emocije. Za kohezivne porodice karakteristično je i aktivno prevladavanje, koje u velikoj meri uključuje i mobilisanje mreže socijalne podrške. I ovaj rezultat nije 
neočekivan, s obzirom na to da kohezivnost u porodici ima za cilj da ostvari veći nivo osećanja sigurnosti i zaštićenosti adolescenta, tj. svesti da u stresnim situacijama ima na koga da se osloni i da zatraži pomoć. Moguće je da adolescenti iz kohezivnih porodica imaju povoljniju procenu vlastitih resursa za prevladavanje stresa, što dovodi do spremnosti adolescenta da aktivno pristupa stresnim situacijama.

Rezultati su takođe pokazali da je na emocije usmereno prevladavanje, karakterističnije za adolescente koji žive u porodicama sa višim nivoom fleksibilnosti, mada se radi o slabijoj povezanosti nego kada je u pitanju kohezivnost. S obzirom na to da porodice sa višim nivoom fleksibilnosti karakteriše lakša mogućnost promene pravila i uloga u porodici, može biti da upravo ovakvo okruženje deluje podržavajuće kada su u pitanju pokušaji da se uspostavi emocionalna regulacija. Sa druge strane, adolescenti koji odrastaju u manje fleksibilnim (rigidnim) porodicama, bivaju sputani u svojim aktivnostima krutim pravilima i odnosima u porodici, što može imati za posledicu manje efikasno prevladavanje stresa.

Podaci o značajnoj pozitivnoj povezanosti kohezivnosti i fleksibilnosti sa aktivnim i na emocije usmerenim strategijama prevladavanja u skladu su sa jednom od polaznih hipoteza Olsonovog cirkumpleks modela. Naime, Olson pretpostavlja da će porodice sa balansiranim nivoima kohezivnosti i fleksibilnosti imati bolje osnove za adaptivniji odgovor na stres, zahvaljujući mehanizmima, veštinama i resursima kojima porodica menja svoje odnose i uloge kako bi adekvatno odgovorila na zahteve stresnih situacija i prilagodila se potrebama svih svojih članova (Olson, 1999; Kouneski, 2000; Olson, Gorall, 2003). Ovu teorijsku postavku potvrdile su brojna istraživanja i studije slučaja. Martoz-Baden i Calvin su u istraživanju koje je uključivalo 72 porodice pokazali da su viši nivoi kohezivnosti i fleksibilnosti značajno povezani sa adaptivnijim strategijama prevladavanja kod adolescenata (Martoz-Baden, Calvin, 1989, prema Kouneski 2000).

U istraživanju prikazanom ovim radom, kohezivnost se pokazala kao značajniji korelat strategija prevladavanja, nego što je to fleksibilnost porodice. $\mathrm{S}$ obzirom da je istraživanje obuhvatilo procene adolescenata, ovo može biti specifičnost uzorka. Naime, kohezivnost podrazumeva veštine porodice da balansira potrebe za zajedništvom i nezavisnošću. Balansirano kohezivni sistemi omogućavaju adekvatan nivo nezavisnosti i individuacije, što su zadaci za koje se vezuju neki od najznačajnijih razvojnih stresora za adolescente. U tom smislu, odgovarajuć nivo kohezivnosti na ovom uzrastu može biti značajan činilac spremnosti adolescenta da se nosi sa aktuelnim stresorima. Značaj toplih, podržavajućih odnosa za razvoj aktivnih strategija prevladavanja stresa 
pokazale su i druge studije (Kliewer i sar, 1996, Zimmer-Gembeck, Locke, 2007).

Ovo istraživanje otvorilo je značajno pitanje načina na koji funkcionalnost porodičnog sistema može podržati adaptivno prevaladavanje stresa kod svojih članova, pa je važno naglasiti i njegova ograničenja. Pre svega, istraživanjem je obuhvaćena populacija porodica bez evidentnih psihičkih teškoća, te je potreban dodatan rad kako bi se ukazalo na specifičnosti odnosa kohezivnosti i fleksibilnosti porodičnih sistema i strategija prevladavanja u disfunkcionalnim porodičnim okruženjima. Takođe, istraživanjem su obuhvaćene samo procene koje o karakteristikama porodica daju adolescenti, što, s obzirom na njihove uzrasne karakteristike, može značajno da izmeni realnu sliku porodičnih odnosa. Da bi se dobila realnija predstava o karakteristikama i funkcionalnosti porodica i precizniji pokazatelji relacija između karakteristika porodice i strategija prevladavanja pojedinih njenih članova, potrebno je u dalja istraživanja ove tematike uključiti i roditelje, kao i druge, ne samo upitničke, načine procene porodičnog sistema. Takođe, s obzirom na saznanja o efektima prolongiranih ili frekventnih stresnih iskustava, kako na strategije prevladavanja tako i na funkcionalnost porodičnih sistema, kumulativne i akutne efekte stresa bi trebalo u daljim istraživanjima kontrolisati.

\section{Reference}

Baer, J. (2002). Is family cohesion a risk or protective factor during adolescent development, Journal of Marriage and Family, 64, 3-18.

Byrne, D. (1964). Repression-sensitization as a dimension of personality. In: B.A. Maher (Ed.), Progress in experimental personality research (Vol. 1). New York: Academic Press.

Ebata, A. T. \& Moos, R. H. (1991). Coping and adjustment in distressed and healthy adolescents. Journal of Applied Developmental Psychology, 12, 33-54.

Farrell, P. M. \& Barnes, M. G. (1993). Family systems and social support: A test of the effects of cohesion and adaptability on the functioning of parents and adolescents, Journal of Marriage and Family, Vol.55, No.1, retrieved July 10, 2007 from http://www.jstor.org

Haan, N. (1977). Coping and defending. New York: Academic Press. 
Kliewer W., Fearnow M. D., Miller P. A (1996). Coping socialization in middle childhood: Test of maternal and paternal influences. Child Development, 67, 2239-2357.

Kouneski E. (2000). The family circumplex model, FACES II and FACES III: Overview of research and applications. Retrieved from www.facesiv.com

Krohne, H.W. (1993). Vigilance and cognitive avoidance as concepts in coping research. In H.W. Krohne (Ed.), Attention and avoidance: Strategies in coping with aversiveness. Seattle, WA: Hogrefe \& Huber.

Lazarus, R.S., \& Folkman, S. (1984). Stress, appraisal, and coping. New York: Springer.

Miller, S.M. (1987). Monitoring and blunting: Validation of a questionnaire to assess styles of information seeking under threat. Journal of Personality and Social Psychology, 52, 345-353.

Mitić, M. (1997). Porodica i stres. Beograd: Institut za psihologiju.

Olson, D. H. \& Gorall, D. M. (2003). Circumplex model of marital and family systems, F. Walsh (Ed.) Normal family processes ( $\left.3^{\text {rd }} \mathrm{Ed}\right)$ New York: Guilford.

Olson D. H. (1999). Circumplex model of marital and family systems. Journal of Family therapy, 22, 144-167.

Reisch, K. S., Henriques, J., Chanchong, W. (2003). Effects of communication skills training of parents and young adolescents from extreme family types, Journal of Child and Adolescents Psychiatric Nurising 10/1/03, retrieved Jan. 17, 2008 from http://www.findarticles.com

Roth, S., \& Cohen, L.J. (1986). Approach, avoidance, and coping with stress. American Psychologist, 41, 813-819.

Vaillant, G.E. (1977). Adaptation to life. Boston, MA: Little, Brown.

Zimmer-Gembeck M. J. , Locke, E. M. (2007). The socialization of adolescent coping behaviors: Relationship with families and teachers. Journal of Adolescence, 30, 1-16.

Zotović, M. (2004). Stres $i$ mentalno zdravlje dece: studija posledica bombardovanja. Beograd: Zadužbina Andrejević.

Zotović, M., Petrović, J., Bašić, A. (2008). Prevladavanje stresa kod adolescenata: relacije sa osobinama ličnosti i indikatorima mentalnog zdravlja. Neobjavljeno istraživanje. Filozofki fakultet, Univerzitet u Novom Sadu, Novi Sad. 


\section{ABSTRACT}

\section{RELATIONS BETWEEN FAMILY CHARACTERISTICS AND COPING STRATEGIES IN ADOLESCENTS}

Marija Zotović, Tijana Telečki, Ivana Mihić, and Jelica Petrović

The aim of this research was to describe relations between coping strategies in adolescents and some characteristics of their families. The sample consisted of 201 adolescents (age 15-19).

Hierarchical factor analysis was used to reduce the initial sample of coping variables, and the relation between coping strategies and the family characteristics was examined with Pearson's correlation coefficient. The results indicated that nine different coping strategies in adolescents could be reduced to three basic dimensions describing coping styles: active coping, emotion-focused coping, and passive coping. The results also showed that there was a statistically significant positive relation between family cohesion, on one side, and emotion- focused coping and active coping, on the other side. There was a statistically positive relation between adaptability in a family system and emotion-focused coping style. There was a statistically significant negative relation between family cohesion and passive coping style.

Key words: family cohesion, adaptability, coping, adolescents 